\title{
Genetic Effects on Corn Seed Longevity
}

\author{
Armando Dornelas Mota ${ }^{1}$, Camila Bastos Ribeiro ${ }^{2}$, Regis de Castro Carvalho ${ }^{2} \&$ Flávia Maria Avelar Gonçalves ${ }^{2}$ \\ ${ }^{1}$ Syngenta Seeds, Uberlândia, MG, Brazil \\ ${ }^{2}$ Universidade Federal de Lavras, Lavras, MG, Brazil \\ Correspondence: Flávia Maria Avelar Gonçalves, Departamento de Biologia, Universidade Federal de Lavras, Cx \\ Postal 3037, CEP: 37200-900, Lavras, MG, Brazil. Tel: 55-35-3829-3166. E-mail: avelar@ufla.br
}

Received: November 21, 2020

Accepted: January 4, 2021

Online Published: January 15, 2021

doi:10.5539/jas.v13n2p56

URL: https://doi.org/10.5539/jas.v13n2p56

\begin{abstract}
This study aimed to elucidate the maternal and paternal genetic effects of the physiological quality of hybrid seed corn over time, as well as the contribution of heterosis for this trait. The seeds of single hybrids, reciprocals and parents were obtained by manual crosses in a complete diallel cross scheme. The analyses of germination and accelerated aging were performed and the data were analyzed with Tukey test and Griffing method. The quadratic components of general combining ability were similar to the effects of specific combining ability and superior to reciprocal, in most evaluation periods, implying that the effects on seed quality characters were attributed to genes of additive effect and genes of non-additive effect. The maternal effect of corn seed longevity was highly significant however its contribution was smaller than general combining ability and specific combining ability effects, but proved to be important in combinations of parents with lower estimate of general combining ability.
\end{abstract}

Keywords: Zea mays, seed quality, shelf life, combining ability, maternal and paternal effect

\section{Introduction}

In maize crop (Zea mays L.), the demand for seed hybrids with high performance and high physiological quality, has increased due to the importance of the crop in Brazilian agricultural scenario, driven mainly by growth in the off-season market (Gomes, E. Von Pinho, R. Von Pinho, \& Vieira, 2000; Oliveira et al., 2015; Santos et al., 2016). The sector of seed production together with the improvement have intensified the search for hybrids that present high seed quality, in order to ensure that farmers will effectively receive seeds with different quality, allowing a successful establishment of crops. According to Oliveira et al. (2013), during corn seed breeding programs, there is no targeting for physiological quality traits, which can compromise the spread of the hybrid on the market.

The term seed quality represents the sum of all attributes, genetic, physical, physiological and sanitary, involved in its production process, as well as the management adopted during its processing and storage, which guarantee high germination and vigor, influencing the establishment of the plants and the high productivity of a crop (Moterle et al., 2011; Moterle et al., 2012; Andrade et al., 2013). Among these attributes, the physiological quality of the seed is important when it desired to obtain new hybrids, since it is related to germination capacity, vigor and longevity of the seed that directly affect the production.

Longevity is directly related to the possibility of storage of the seed for longer periods without loss of quality. The storage process is unable to increase the physiological quality of seed, which can be measured by the vigor and germination tests, however, under unfavorable conditions of temperature and humidity, the deterioration of the seeds can be accelerated, reducing its longevity. Knowledge of storage potential and longevity of seeds is important to the seed companies, production planning, logistics and marketing of hybrid seeds (Nerling, Coelho, \& Nodari, 2013; Nerling, Coelho, \& Brummer, 2018).

There is little information on the mechanisms of genetic control related to the characters involved in the physiological quality of the seeds. According to Laude and Carena (2015), the high performance of corn hybrids is a result of the heterotic effect of cross breeding with good combinatorial capacity. However, the knowledge of these mechanisms is fundamental for the development of suitable selection methods that take into account the physiological quality of the seeds during all phases of the development of a new cultivar (Oliveira et al., 2013). 
According to Gomes et al. (2000), the physiological quality of hybrid seed corn, compared to physiological seed quality of the parents is higher due to the expression of heterosis, that is, the presence of non-additive gene. It was observed that seeds of inbred lines with low physiological traits influencing the physiological quality of hybrid seeds, especially when used as females. Some authors found that the genetic control for quality temperate corn seed is due to additive effects of genes and partly by non-additive effects of genes (Barla-Szabo, Bocsi, Dolinka, \& Odiemah, 1989; Odiemah, 1989). Pesev (1970) verified that there is a maternal effect on the degree of tolerance to low temperatures, the germination and the speed of emergence in the hybrid corn seedlings.

Therefore, this study aims to elucidate the genetic effects of maternal and paternal parents on the physiological quality of hybrid corn seeds, over time, as well as the contribution of heterosis for this trait.

\section{Material and Methods}

\subsection{Location}

The experiment for seeds production of parents and hybrids was carried out in a Syngenta Seeds Production Research area, in Irai de Minas, MG, Brazil, at an altitude of 1,040 meters, coordinates $18^{\circ} 59^{\prime} 28.66^{\prime \prime} \mathrm{S}$ and $47^{\circ} 24^{\prime} 17.56^{\prime \prime} \mathrm{W}$. We used a center pivot irrigation system and the previous crop soybeans RR, with planting in no-till system.

\subsection{Genotypes}

Eight genotypes were selected, originating from a tropical germplasm belonging to Breeding Program of Syngenta Seeds, with contrasting and previously known traits about the physiological quality maintainability of their seeds over time (shelf life).Three genotypes were used with high physiological quality (G1, G2 and G8), three with medium physiological quality (G3, G4 and G5) and two with low physiological quality (G6 and G7). Each genotype was sown in four rows in four meters long, with 0.7 meters between rows, with plant population around 85,000 plants $^{-1} \mathrm{a}^{-1}$, guaranteed by practice of thinning.

\subsection{Obtaining the Seeds}

At flowering time, the genotypes were crossed manually in a complete diallel scheme, therefore the seeds of the crosses were harvested with moisture around $35 \%$, dried in an experimental dryer till $13 \%$ of moisture and during the processing the seed sizes smaller than 18/64 and bigger than 22/64 were discarded, in order to standardize the seed mass. After processing, the seeds were submitted to chemical treatment with fungicides and insecticides, in order to avoid losses during the storage phase in a non-air conditioned environment, during 360 days. The seeds were removed from the general sample and sent for analysis in the laboratory at five different times of evaluation of the physiological quality of the seeds $(0,90,180,270$ and 360 days).

\subsection{Germination Test}

The standard germination test was carried out, according to the Brazilian Rules for Seed Analysis (Brasil, 2009), with four replications of 100 seeds in Germitest paper towel moistened with distilled water in the ratio 2.5 mL.g-1 paper and the germination occurred in a germinating camera $25{ }^{\circ} \mathrm{C}$, and the evaluation of normal seedlings occurred on the fifth day after the test installation and the data were expressed as a percentage.

\subsection{Accelerated Aging Test}

The accelerated or artificial aging test, was done as described by Marcos-Filho (1999). It was carried out with two replications of 100 seeds and each replication was wrapped in a plastic box type gerbox with grille $(11.5 \times$ $11.5 \times 3.5 \mathrm{~cm})$, without overlapping seeds. At the bottom of the box type gerbox with grille $(11.5 \times 11.5 \times 3.5$ $\mathrm{cm}$ ), without overlapping seeds. At the bottom of the box, $40 \mathrm{ml}$ of distilled water was added, establishing an environment with $100 \%$ relative humidity, maintained at the aging chamber (Biochemical Oxygen Demand-BOD) set at $42{ }^{\circ} \mathrm{C}$ for 96 hours. After the period of 96 hours, sowing took place in towel paper, taken at a constant temperature of $25^{\circ} \mathrm{C}$ for five days, and thus after this period, the normal seedlings were quantified and the results were expressed as a percentage.

\subsection{Statistical Analysis}

The data were analyzed considering a completely randomized design, considering all the effects fixed, except the error as random. The averages were calculated using the statistical program JMP ${ }^{\circledR}$ (Sas Institute Inc., 2012), version 10 and compared by Tukey test at $5 \%$ probability. To elucidate the contribution of maternal effect on the physiological quality of corn seeds, using the average for the time of evaluation, the data obtained through the accelerated aging test was carried out diallel analysis by method I of Griffing (1956), which includes $\mathrm{n}^{2}$ number of possible genotypes according to the following model proposed by Cruz, Regazzi, and Carneiro (2012): 


$$
Y_{i j}=m+g_{i}+g_{j}+s_{i j}+r_{i j}+\bar{e}_{i j}
$$

where, $Y_{i j}$ is the average value of the hybrid $\mathrm{ij}(i, j=1,2, \ldots p, i<j) ; m$ is the general average; $g_{i}$, $g_{j}$ are the effects of general combining ability of the $i$-th and $j$-th parent, respectively; $s_{i j}$ is the effect of specific combining ability to cross between the parents of order $i$ and $j ; r_{i j}$ is the reciprocal effect which measures the differences provided by the parent $i$ or $j$ when used as a male or female as the cross $i j$; and $\bar{e}_{i j}$ is the average experimental error associated with the observation $i j$ order. In this model, it is assumed that $s_{i j}=s_{j i}, r_{i j}=-r_{j i}$ and $r_{i i}=0$. To perform the diallel analysis, we used the statistical software version 7.0 Genes (Cruz, 2013).

The general combining ability (GCA) refers to the average combination of a parental hybrid in any combination. The specific combining ability (SCA) is used in cases where the combination of certain parents is higher or lower than expected, based on the average performance of the parents of the hybrid in question. The SCA is directly correlated with heterosis.

\section{Results and Discussion}

During the process of obtaining seeds from genotypes and hybrids by hand pollinated, there are some limitations such as low potential for seed production and flowering difference between the parents, limited amount of seed produced for some materials. Therefore, the genotype G4, as well as all single and reciprocal hybrids produced by him, were removed from the analysis because it did not generate enough seeds for the study.

\subsection{Physiological Quality}

The contrasting genotypes for seed quality were selected based on Syngenta's data history. This assumption was fundamental for the single and reciprocal hybrids expressing different results for the traits evaluated. To compare the average of germination and accelerated aging at different times of evaluation, it was used the Tukey test at $5 \%$ probability. It was verified that the parent G6 presented the lowest averages for the two characters in the different evaluation periods (Table 1).

Table 1. Average results of corn seed germination test (\%) and accelerated aging test (\%) derived from the seven parents (inbred lines) at different times of assessment (days)

\begin{tabular}{llllll}
\hline \multirow{2}{*}{ Parents } & \multicolumn{5}{c}{ Germination (\%) } \\
\cline { 2 - 6 } & 0 & 90 & 180 & 270 & 360 \\
\hline G1 & $96.25 \mathrm{Aab}$ & $97.25 \mathrm{Aa}$ & $98.25 \mathrm{Aa}$ & $95.50 \mathrm{Aab}$ & $95.00 \mathrm{Aa}$ \\
G2 & $97.75 \mathrm{Aa}$ & $97.25 \mathrm{Aa}$ & $98.00 \mathrm{Aa}$ & $97.00 \mathrm{Aa}$ & $91.00 \mathrm{Bab}$ \\
G5 & $93.50 \mathrm{Aab}$ & $89.50 \mathrm{Ac}$ & $94.75 \mathrm{Aab}$ & $91.50 \mathrm{Abc}$ & $91.50 \mathrm{Aab}$ \\
G6 & $97.25 \mathrm{Aab}$ & $94.50 \mathrm{ABabc}$ & $94.50 \mathrm{ABab}$ & $92.00 \mathrm{ABabc}$ & $88.50 \mathrm{Bab}$ \\
G7 & $92.75 \mathrm{Ab}$ & $80.00 \mathrm{Cd}$ & $91.50 \mathrm{ABb}$ & $88.50 \mathrm{ABc}$ & $85.50 \mathrm{BCb}$ \\
G8 & $94.50 \mathrm{Aab}$ & $90.25 \mathrm{Abc}$ & $91.25 \mathrm{Ab}$ & $77.75 \mathrm{Bd}$ & $67.50 \mathrm{Cc}$ \\
\hline & $94.75 \mathrm{Aab}$ & $96.00 \mathrm{Aab}$ & $96.25 \mathrm{Aa}$ & $95.25 \mathrm{Aab}$ & $94.50 \mathrm{Aa}$ \\
\hline G1 & & Accelerated aging $(\%)$ & $92.50 \mathrm{Aa}$ & $57.50 \mathrm{Bb}$ \\
G2 & $92.00 \mathrm{Aa}$ & $95.00 \mathrm{Aa}$ & $89.50 \mathrm{Aa}$ & $94.00 \mathrm{Aa}$ & $72.00 \mathrm{Bb}$ \\
G3 & $96.00 \mathrm{Aa}$ & $96.00 \mathrm{Aa}$ & $94.00 \mathrm{Aa}$ & $63.50 \mathrm{Bb}$ & $20.00 \mathrm{Cc}$ \\
G5 & $83.50 \mathrm{Ab}$ & $81.00 \mathrm{Ab}$ & $65.50 \mathrm{Bb}$ & $19.00 \mathrm{Cc}$ & $22.50 \mathrm{Cc}$ \\
G6 & $90.00 \mathrm{Aab}$ & $78.00 \mathrm{Bb}$ & $77.50 \mathrm{Bab}$ & $11.00 \mathrm{BCd}$ & $2.00 \mathrm{Cd}$ \\
G7 & $42.00 \mathrm{Ad}$ & $17.50 \mathrm{Bd}$ & $37.50 \mathrm{Ac}$ & $2.50 \mathrm{De}$ & $0.00 \mathrm{Dd}$ \\
G8 & $69.50 \mathrm{Ac}$ & $39.50 \mathrm{Bc}$ & $24.00 \mathrm{Cc}$ & $93.00 \mathrm{Aa}$ & $94.50 \mathrm{Aa}$ \\
\hline
\end{tabular}

Note. Means followed by the same letter, lowercase in the column and uppercase in the row, do not differ by Tukey test at $5 \%$ probability.

There was a highly significant difference between the evaluation periods $(\mathrm{P}<0.01)$. Despite of the significant difference between parents, at the time zero germination analysis, all parents had high initial germination rates (above 90\%), demonstrating the high physiological quality of seed produced for the experiment (Table 1).

The parent G8 stood out compared to the others due to the traits of maintaining the germination and vigor throughout the evaluation period (360 days), without quality losses. The opposite occurred with the G6 and G7 parents that especially the accelerated aging test showed undesirable results from the time zero evaluation (Table 1). The accelerated aging test was considered by Gomes et al. (2000) and Nerling et al. (2013) as the best test 
force to determine the physiological quality of seeds, to compare several tests that infer about the germination, as germination field, cold test, electrical conductivity, site in germination and emergence speed index.

\subsection{Diallel Analysis}

Because of the work reported above, about testing and diallel analysis, we only used data from accelerated aging test. The diallel analysis by Griffing method I (1956), allow us to evaluate the particular behavior of the crossing, as well as their reciprocal, due to cytoplasmatic genes, located in chloroplasts and mitochondria. According to Cruz et al. (2012) and Fan et al. (2013), the reciprocal effects of GCA allow also to identify which parent should be used as male or female line in the selected crossing.

In the analysis of variance of accelerated aging data, evaluated over time obtained by Griffing diallel (1956) analysis, it was observed that all sources of variation were significant at $1 \%$ probability $(\mathrm{P}<0.01)$ (Table 2$)$. Besides the heterosis, represented by the SCA, commonly associated with the hybrid superiority effect in relation to the lines, as the storage potential feature, there are other effects, such as the predominance of additive effects, which were significant $(\mathrm{P}<0.01)$ for GCA and maternal effects through their mutual analysis. The significance for the GCA and SCA are indicative of additive effects associated with the GCA and non-additive, associated with the SCA, in the genetic control of corn seed longevity evaluated.

Table 2. Summary of variance analysis for parents, single hybrids and reciprocal according to accelerated aging test data for the different evaluation times (days) by Griffing test (1956), Model $1\left(\mathrm{n}^{2}\right)$.

\begin{tabular}{lllllll}
\hline \multirow{2}{*}{ SV } & \multirow{2}{*}{ DF } & \multicolumn{5}{c}{ MS } \\
\cline { 3 - 7 } & & 0 & 90 & 180 & 270 & 360 \\
\hline Parents & 48 & $177.6^{* *}$ & $454.3^{* *}$ & $519.0^{* *}$ & $1208.5^{* *}$ & $1463.3^{* *}$ \\
GCA & 6 & $500.6^{* *}$ & $1663.0^{* *}$ & $1678.6^{* *}$ & $2236.1^{* *}$ & $4753.5^{* *}$ \\
SCA & 21 & $230.7^{* *}$ & $470.6^{* *}$ & $518.4^{* *}$ & $1214.0^{* *}$ & $1157.2^{* *}$ \\
Reciprocal & 21 & $32.2^{* *}$ & $92.6^{* *}$ & $188.3^{* *}$ & $909.3^{* *}$ & $829.3^{* *}$ \\
Residue & & $2.9(49)^{+}$ & $5.6(47)^{+}$ & $12.6(47)^{+}$ & $7.4(41)^{+}$ & $12.7(37)^{+}$ \\
\hline
\end{tabular}

Note. ${ }^{* *}$ Significant $\mathrm{F}$ test at $1 \%$ probability.

+ The number in parenthesis represents the degree of freedom of the residue at different times of evaluation.

GCA: general combining ability; SCA: specific combining ability.

The results differ from the ones found by Gomes et al. (2000), in which the effect of the superiority of hybrid in relation to parents for the trait of storage potential measured by accelerated aging test, through diallel with six parents and thirty hybrids, was due to heterosis. That is, by non-additive effects, determined by SCA. Reis, Pereira, Silva, and Meireles (2011) verified heterosis for germination and vigor in hybrid sweet corn seeds when compared to their parents and Prazeres and Coelho (2016) observed that accelerated aging vigor test was effective in determining the genetic divergence between the lines and the hybrids $(48.6 \%)$ and indicated a greater heterosis for the hybrids with respect to the line.

However, in studies conducted by Odiemah (1989), inheritance of traits related to the quality of seeds occurred, mainly due to the additive effect of genes and partly as consequence of the non-additive effect. Barla-Szabo et al. (1989) also investigated the genetic determination of seed vigor and found greater importance of the additive effect of genes.

Regarding the maternal effect on seed longevity, the quadratic components of the reciprocals were lower than the SCA and GCA. However, there was significance $(\mathrm{P}<0.01)$ for the reciprocal effect, confirming the existence of maternal effect on the quality of corn hybrid seed over time.

The natural deterioration caused by the storage of seeds in uncontrolled conditions of temperature and air humidity, caused the difference between the quadratic components of the GCA and reciprocal in relation to the SCA, showing the greater contribution of additive effect of genes on storage capacity (shelf life) of hybrid corn seeds, in accordance with the results found by Barla-Szabo et al. (1989), and Odiemah (1989) (Figure 1). 


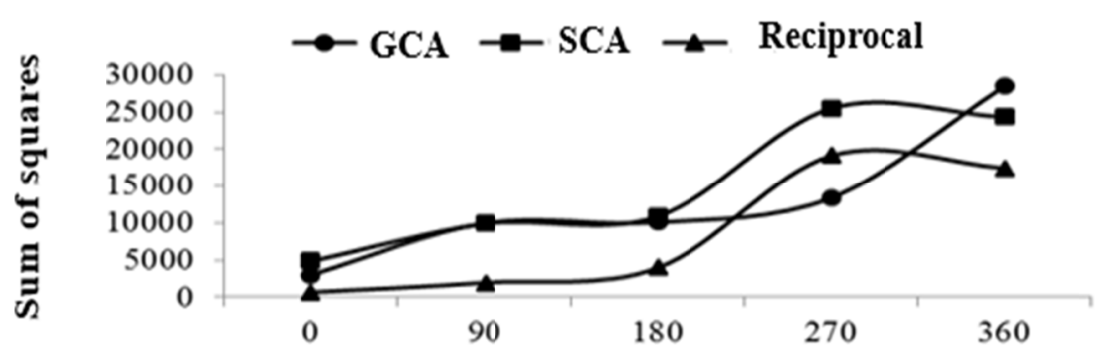

Figure 1. Sum of squares of the effects of general combining ability (GCA), specific combining ability (SCA) and reciprocal combining ability, in relation to the different evaluation times in days

It can be estimated by the general combining ability of genotypes (g) in the diallel analysis of Griffing (1956). This information is extremely useful to plant breeders because it depends on the additive variation of each genotype. Thus, the cross between parents with higher general combining ability (GCA) is expected to generate potentially higher descendants, thus enabling the selection of genotypes for the desired feature (Ramalho, Abreu, Santos, \& Nunes, 2012; Cabral et al., 2013; Conrado et al., 2014).

By the GCA estimates ( $\mathrm{g}$ ), at different times of evaluation, it can be observed that the contrasting genotypes were selected as predetermined conditions for selection (Table 3). The differences between the estimates of the GCA for the same genotype between the different evaluation periods are possibly explained by the effect of storage in uncontrolled conditions of temperature and relative humidity.

Table 3. Estimates of general combining ability $\left(g_{i j}\right)$ for the accelerated aging test, in different evaluation periods (days) of corn seeds

\begin{tabular}{lllllll}
\hline \multirow{2}{*}{$\left.g_{i j}\right)$} & \multicolumn{5}{c}{ Evaluation periods (days) } & \multirow{2}{*}{ Averages } \\
\cline { 2 - 5 } & 0 & 90 & 5.50 & 270 & 360 & 4.032 \\
G1 & 2.709 & 5.586 & 5.341 & 8.724 & -2.200 & 5.969 \\
G3 & 3.066 & 6.221 & 6.934 & 9.020 & 4.603 & -1.135 \\
G5 & -0.041 & 0.800 & -3.659 & 5.031 & -7.807 & -0.412 \\
G6 & 1.745 & 1.507 & 2.470 & -3.467 & -4.319 & -9.927 \\
G7 & -8.791 & -14.797 & -8.089 & -12.566 & -5.393 & -9.295 \\
G8 & -1.505 & -5.332 & -11.339 & -10.572 & -17.730 & 9.279 \\
\hline DP(Gi) & 2.816 & 6.014 & 8.341 & 3.830 & 25.393 & 0.483 \\
DP(Gi-Gj) & 0.296 & 0.414 & 0.621 & 0.475 & 0.613 & 0.739 \\
\hline
\end{tabular}

Note. DP: Standard Deviation.

The parent G8 stands out compared to the other by the high value of GCA (Table 3). All single and reciprocal hybrids, evaluated in 270 and 360 days, were not statistically different $(\mathrm{P}<0.05)$ for the accelerated aging test, Tukey test at 5\% probability. Except when crossed with the parent G6, for reciprocal cross G6/G8 (Table 4). This, in turn, showed a mean GCA value inferior to the parents (Table 3). 
Table 4. Average results of the accelerated aging test (\%), the different evaluation periods (days) to compare the single hybrids, reciprocals and parents based on the G8 genotype crossed with the genotypes G1, G2, G5, G6 and G7

\begin{tabular}{llllll}
\hline \multirow{2}{*}{ Parents/Hybrids } & \multicolumn{5}{c}{ Evaluation periods (days) } \\
\cline { 2 - 5 } & 0 & 90 & 180 & 270 & 360 \\
\hline $\mathrm{G} 8$ & $93.5 \mathrm{bc}$ & $93.5 \mathrm{a}$ & $94.5 \mathrm{a}$ & $93.0 \mathrm{a}$ & $94.5 \mathrm{a}$ \\
$\mathrm{G} 8 / \mathrm{G1}^{+}$ & $97.0 \mathrm{ab}$ & $97.0 \mathrm{a}$ & $96.0 \mathrm{a}$ & $96.0 \mathrm{a}$ & $97.5 \mathrm{a}$ \\
$\mathrm{G} 1$ & $92.0 \mathrm{c}$ & $95.0 \mathrm{a}$ & $89.5 \mathrm{a}$ & $92.5 \mathrm{a}$ & $57.5 \mathrm{~b}$ \\
$\mathrm{G} 1 / \mathrm{G} 8^{+}$ & $97.5 \mathrm{a}$ & $97.0 \mathrm{a}$ & $96.0 \mathrm{a}$ & $88.0 \mathrm{a}$ & - \\
$\mathrm{G} 8$ & $93.5 \mathrm{~b}$ & $93.5 \mathrm{a}$ & $94.5 \mathrm{a}$ & $93.0 \mathrm{a}$ & $94.5 \mathrm{a}$ \\
$\mathrm{G} 8 / \mathrm{G} 2^{+}$ & $97.0 \mathrm{a}$ & $97.0 \mathrm{a}$ & $97.5 \mathrm{a}$ & $98.0 \mathrm{a}$ & - \\
$\mathrm{G} 2$ & $96 \mathrm{ab}$ & $96.0 \mathrm{a}$ & $94.0 \mathrm{a}$ & $94.0 \mathrm{a}$ & $72.0 \mathrm{~b}$ \\
$\mathrm{G} 2 / \mathrm{G}^{+}$ & $97.0 \mathrm{a}$ & $96.5 \mathrm{a}$ & $98.0 \mathrm{a}$ & $95.0 \mathrm{a}$ & $96.5 \mathrm{a}$ \\
$\mathrm{G} 8$ & $93.5 \mathrm{ab}$ & $93.5 \mathrm{a}$ & $94.5 \mathrm{a}$ & $93.0 \mathrm{a}$ & $94.5 \mathrm{a}$ \\
$\mathrm{G} 8 / \mathrm{G}^{+}$ & $96.5 \mathrm{a}$ & $92.0 \mathrm{a}$ & $90.0 \mathrm{a}$ & $97.0 \mathrm{a}$ & $91.5 \mathrm{a}$ \\
$\mathrm{G} 5$ & $90.0 \mathrm{~b}$ & $78.0 \mathrm{~b}$ & $77.5 \mathrm{~b}$ & $19.0 \mathrm{~b}$ & $22.5 \mathrm{~b}$ \\
$\mathrm{G} 5 / \mathrm{G}^{+}$ & $96.5 \mathrm{a}$ & $97.5 \mathrm{a}$ & $95.5 \mathrm{a}$ & - & $97.0 \mathrm{a}$ \\
$\mathrm{G} 8$ & $93.5 \mathrm{a}$ & $93.5 \mathrm{a}$ & $93.5 \mathrm{a}$ & $93.0 \mathrm{a}$ & $94.5 \mathrm{a}$ \\
$\mathrm{G} 8 / \mathrm{G6}^{+}$ & $96.0 \mathrm{a}$ & $96.5 \mathrm{a}$ & $93.5 \mathrm{a}$ & $96.0 \mathrm{a}$ & $95.0 \mathrm{a}$ \\
$\mathrm{G} 6$ & $42.0 \mathrm{~b}$ & $17.5 \mathrm{c}$ & $37.5 \mathrm{~b}$ & $11.0 \mathrm{c}$ & $2.0 \mathrm{c}$ \\
$\mathrm{G} 6 / \mathrm{G}^{+}$ & $95.5 \mathrm{a}$ & $88.0 \mathrm{~b}$ & $91.0 \mathrm{a}$ & $67.0 \mathrm{~b}$ & $75.0 \mathrm{~b}$ \\
$\mathrm{G} 8$ & $93.5 \mathrm{a}$ & $93.5 \mathrm{a}$ & $93.5 \mathrm{a}$ & $93.0 \mathrm{a}$ & $94.5 \mathrm{a}$ \\
$\mathrm{G} 8 / \mathrm{G}^{+}$ & $97.0 \mathrm{a}$ & $96.0 \mathrm{a}$ & $96.0 \mathrm{a}$ & $97.0 \mathrm{a}$ & $95.5 \mathrm{a}$ \\
$\mathrm{G} 7$ & $69.5 \mathrm{~b}$ & $39.5 \mathrm{~b}$ & $39.5 \mathrm{~b}$ & $2.5 .0 \mathrm{~b}$ & $0.0 \mathrm{~b}$ \\
$\mathrm{G} 7 / \mathrm{G} 8^{+}$ & $97.0 \mathrm{a}$ & $98.0 \mathrm{a}$ & $98.0 \mathrm{a}$ & $96.5 \mathrm{a}$ & $91.5 \mathrm{a}$ \\
\hline
\end{tabular}

Note. Means followed by the same letter in the column belong to the same grouping by Tukey test at $5 \%$ probability.

+ (Female/male): order of female and male parents in crosses.

The results for the G8 genotype agree to those reported by Barla-Szabo et al. (1989) and Odiemah (1989), which related the traits associated with quality seeds to the general combining ability of the parents.

Other diallel crosses involving parents with low GCA estimate by Griffing method, in the case of the G6 genotypes, for example, perform differently than that found for the G8 genotypes. In this case, when used as a female in diallel, single hybrids were always statistically lower $(\mathrm{P}<0.05)$ by Tukey test at $5 \%$ probability, for the single reciprocal hybrids, for 270 and 360 days evaluation (Table 5). 
Table 5. Average results of the accelerated aging test (\%), the different evaluation periods (days), compared to the single hybrids, reciprocal and parents based on the G6 genotype crossing with G2 genotypes G3, G5 and G8

\begin{tabular}{llllll}
\hline \multirow{2}{*}{ Parents/Hybrids } & \multicolumn{5}{c}{ Evaluation periods (days) } \\
\cline { 2 - 6 } & 0 & 90 & 180 & 270 & 360 \\
\hline $\mathrm{G} 6$ & $42.0 \mathrm{c}$ & $17.5 \mathrm{c}$ & $37.5 \mathrm{~b}$ & $11.0 \mathrm{c}$ & $2.0 \mathrm{c}$ \\
$\mathrm{G} 6 / \mathrm{G} 2^{+}$ & $89.0 \mathrm{~b}$ & $81.5 \mathrm{~b}$ & $79.0 \mathrm{a}$ & $96.0 \mathrm{a}$ & $59.0 \mathrm{~b}$ \\
$\mathrm{G} 2$ & $96.0 \mathrm{ab}$ & $96.0 \mathrm{a}$ & $94.0 \mathrm{a}$ & $94.0 \mathrm{a}$ & $72.0 \mathrm{~b}$ \\
$\mathrm{G} 2 / \mathrm{G} 6^{+}$ & $98.0 \mathrm{a}$ & $95.0 \mathrm{a}$ & $98.0 \mathrm{a}$ & $77.5 \mathrm{~b}$ & $97.0 \mathrm{a}$ \\
$\mathrm{G} 6$ & $42.0 \mathrm{c}$ & $17.5 \mathrm{~b}$ & $37.5 \mathrm{c}$ & $11.0 \mathrm{c}$ & $2.0 \mathrm{c}$ \\
$\mathrm{G} 6 / \mathrm{G} 3^{+}$ & $81.5 \mathrm{~b}$ & $70.5 \mathrm{a}$ & $82.5 \mathrm{ab}$ & $93.5 \mathrm{a}$ & $75.5 \mathrm{a}$ \\
$\mathrm{G} 3$ & $83.5 \mathrm{~b}$ & $81.0 \mathrm{a}$ & $65.5 \mathrm{~b}$ & $63.5 \mathrm{~b}$ & $20.0 \mathrm{~b}$ \\
$\mathrm{G} 3 / \mathrm{G6}^{+}$ & $93.5 \mathrm{a}$ & $89.0 \mathrm{a}$ & $91.5 \mathrm{a}$ & $94.5 \mathrm{a}$ & $91.5 \mathrm{a}$ \\
$\mathrm{G} 6$ & $42.0 \mathrm{c}$ & $17.5 \mathrm{c}$ & $37.5 \mathrm{c}$ & $11.0 \mathrm{~d}$ & $2.0 \mathrm{c}$ \\
$\mathrm{G} 6 / \mathrm{G} 5^{+}$ & $84.0 \mathrm{~b}$ & $71.5 \mathrm{~b}$ & $69.5 \mathrm{~b}$ & $55.5 \mathrm{~b}$ & $27.5 \mathrm{~b}$ \\
$\mathrm{G} 5$ & $90.0 \mathrm{ab}$ & $78.0 \mathrm{~b}$ & $77.5 \mathrm{ab}$ & $19.0 \mathrm{c}$ & $22.5 \mathrm{~b}$ \\
$\mathrm{G} 5 / \mathrm{G6}^{+}$ & $95.5 \mathrm{a}$ & $94.5 \mathrm{a}$ & $97.0 \mathrm{a}$ & $92.0 \mathrm{a}$ & $73.0 \mathrm{a}$ \\
$\mathrm{G} 6$ & $42.0 \mathrm{~b}$ & $17.5 \mathrm{c}$ & $37.5 \mathrm{~b}$ & $11.0 \mathrm{c}$ & $2.0 \mathrm{c}$ \\
$\mathrm{G} 6 / \mathrm{G} 8^{+}$ & $95.5 \mathrm{a}$ & $88.0 \mathrm{~b}$ & $91.0 \mathrm{a}$ & $67.0 \mathrm{~b}$ & $75.0 \mathrm{~b}$ \\
$\mathrm{G} 8$ & $93.5 \mathrm{a}$ & $93.5 \mathrm{ab}$ & $94.5 \mathrm{a}$ & $93.0 \mathrm{a}$ & $94.5 \mathrm{a}$ \\
$\mathrm{G} 8 / \mathrm{G6}^{+}$ & $96.0 \mathrm{a}$ & $96.5 \mathrm{a}$ & $93.5 \mathrm{a}$ & $96.0 \mathrm{a}$ & $95.0 \mathrm{a}$ \\
\hline
\end{tabular}

Note. Means followed by the same letter in the column belong to the same grouping by Tukey test at $5 \%$ probability.

+ (Female/male): order of female and male parents in crosses.

Single hybrids, originated from the parent G6 using it as a female were inferior to their reciprocal. It was possible to infer that a maternal effect has a greater effect on the maintenance of germination and vigor of seeds than the paternal effect or simply heterosis. In general, single hybrids and reciprocal, originated from other crossings, showed results that varied according to the parents used, possibly is due to the specific combining ability (SCA), which was highly significant $(\mathrm{P}<0.01)$ (Table 2 ).

Despite the effect of specific combining ability was useful to indicate the best hybrid combinations, it does not show how the parent must be used in the cross, as female or male. To make such an inference, it is necessary to use estimates of reciprocal effects $\left(r_{i j}\right)$.

In the analysis of the estimates for the reciprocal effect, single hybrids must be observed $\left(s_{i j}\right)$, compared with its reciprocal $\left(r_{i j}\right)$ (Table 6). As for the reciprocal effect for most of the hybrids in the different evaluation times, there was significance, with higher or lower estimates for single hybrids. 
Table 6. Estimate of SCA of single hybrids $\left(s_{i j}\right)$ and reciprocal hybrids $\left(r_{i j}\right)$ in the different evaluation times for the accelerated aging data

\begin{tabular}{|c|c|c|c|c|c|c|c|c|c|c|}
\hline \multirow{2}{*}{ Hybrids } & \multicolumn{5}{|c|}{ Single hybrids $\left(s_{i j}\right)$} & \multicolumn{5}{|c|}{ Reciprocal hybrids $\left(r_{i j}\right)$} \\
\hline & 0 & 90 & 180 & 270 & 360 & 0 & 90 & 180 & 270 & 360 \\
\hline $\mathrm{G} 1 \times \mathrm{G} 2$ & -3.2 & -5.0 & -4.5 & -5.2 & -7.2 & -2.0 & -1.8 & -0.8 & -5.0 & -17.8 \\
\hline $\mathrm{G} 1 \times \mathrm{G} 3$ & -0.4 & 1.4 & 4.1 & -0.2 & 3.0 & -1.8 & -0.3 & 1.3 & ns & -1.2 \\
\hline $\mathrm{G} 1 \times \mathrm{G} 5$ & -0.2 & -0.8 & -3.0 & 10.8 & -10.3 & 0.3 & 1.3 & -1.3 & -2.5 & -24.8 \\
\hline $\mathrm{G} 1 \times \mathrm{G} 6$ & 8.4 & 5.5 & 5.3 & 8.8 & 18.5 & 1.3 & 10.3 & 8.5 & 4.5 & 2.1 \\
\hline $\mathrm{G} 1 \times \mathrm{G} 7$ & 4.1 & 6.5 & 9.8 & 11.6 & 0.8 & 0.3 & 1.3 & 3.8 & 0.5 & -8.9 \\
\hline $\mathrm{G} 1 \times \mathrm{G} 8$ & -1.7 & -3.1 & -4.1 & 1.0 & -1.7 & 0.3 & ns & ns & -4.0 & -11.0 \\
\hline $\mathrm{G} 2 \times \mathrm{G} 3$ & 0.5 & -1.0 & -0.2 & -10.5 & -3.1 & 1.0 & 0.5 & 5.5 & 9.0 & 18.8 \\
\hline $\mathrm{G} 2 \times \mathrm{G} 5$ & 0.2 & 0.0 & -0.4 & 4.4 & 9.0 & 0.5 & 0.8 & 0.6 & 3.6 & 17.7 \\
\hline $\mathrm{G} 2 \times \mathrm{G} 6$ & 5.8 & 8.4 & 3.2 & 1.2 & 13.7 & 4.5 & 6.8 & 9.5 & 9.3 & 19.0 \\
\hline $\mathrm{G} 2 \times \mathrm{G} 7$ & 2.7 & 6.4 & 12.2 & -3.1 & -4.7 & -0.3 & -0.8 & 0.3 & 14.6 & 13.9 \\
\hline $\mathrm{G} 2 \times \mathrm{G} 8$ & -2.4 & -3.9 & -4.0 & -5.2 & -5.4 & $\mathrm{~ns}$ & -0.3 & 0.3 & -1.5 & 6.9 \\
\hline $\mathrm{G} 3 \times \mathrm{G} 5$ & 2.3 & 0.2 & 7.2 & 8.6 & 18.8 & ns & 3.0 & 1.0 & 7.3 & 8.7 \\
\hline $\mathrm{G} 3 \times \mathrm{G} 6$ & 2.9 & 5.3 & 12.3 & 23.0 & 24.6 & 6.0 & 9.3 & 4.5 & 0.5 & 8.0 \\
\hline $\mathrm{G} 3 \times \mathrm{G} 7$ & 3.8 & 8.3 & -11.9 & 7.3 & 0.1 & -2.3 & -1.8 & -2.3 & 0.8 & -0.1 \\
\hline $\mathrm{G} 3 \times \mathrm{G} 8$ & 0.8 & -5.3 & 2.1 & -3.2 & 0.1 & $\mathrm{~ns}$ & 2.0 & -0.3 & -1.2 & -4.3 \\
\hline G5×G6 & 3.3 & 7.8 & 2.4 & 1.1 & -5.1 & 5.8 & 11.5 & 13.8 & 18.3 & 22.8 \\
\hline $\mathrm{G} 5 \times \mathrm{G} 7$ & 2.8 & 7.4 & 12.2 & 15.8 & 13.4 & -0.5 & 1.5 & 1.8 & 11.8 & 20.7 \\
\hline $\mathrm{G} 5 \times \mathrm{G} 8$ & -1.5 & -1.2 & -4.5 & 1.7 & 8.1 & $\mathrm{~ns}$ & 2.8 & 2.8 & -1.6 & 2.8 \\
\hline $\mathrm{G} 6 \times \mathrm{G} 7$ & 5.3 & 1.8 & 4.0 & -2.4 & 0.5 & -8.0 & -8.1 & -7.0 & 28.5 & -11.8 \\
\hline G6×G8 & 8.3 & 12.6 & 5.6 & 11.7 & 0.0 & -0.3 & -4.3 & -1.3 & -14.5 & -10.0 \\
\hline $\mathrm{G} 7 \times \mathrm{G} 8$ & 2.2 & 7.9 & 13.6 & 23.2 & 20.4 & $\mathrm{~ns}$ & 1.0 & ns & -4.9 & -2.0 \\
\hline $\mathrm{DP} 1$ & 0.73 & 1.02 & 1.54 & 1.18 & 1.52 & 0.8 & 1.2 & 1.8 & 1.4 & 1.8 \\
\hline DP 2 & 1.01 & 1.41 & 2.12 & 1.62 & 2.09 & 1.2 & 1.7 & 2.5 & 1.9 & 2.5 \\
\hline
\end{tabular}

Note. DP1: Standard deviation $\left(s_{i j}\right)-\left(r_{i j}\right)$; DP2: Standard deviation $\left(s_{i j}-s_{k l}\right)-\left(r_{i j}-r_{k l}\right)$; ns: Not significant for the test of reciprocal.

For the G1 genotype, considering 360 days, all estimates of single hybrids were higher than the reciprocal, implying the superiority of this genotype as a female when compared to other parents. The opposite occurred with the G2 genotype, in which the estimate of the reciprocal was superior to single hybrids.

For the G3 genotype, estimates of single hybrids were superior to all other genotypes, except for the G1 genotype, whose $\mathrm{G} 1 \times \mathrm{G} 3$ combination was superior to $\mathrm{G} 3 \times \mathrm{G} 1$. In this case, $\mathrm{G} 1$ and $\mathrm{G} 3$ have good potential for use as females. Estimates of the SCA are relatively low, expressing low deviation of hybrids in relation to what would be expected based on general combining abilities of parents.

For genotype G5, estimates of hybrids were higher than those in reciprocal cross with the G8 and G2 genotypes. It was lower compared to the others, expressing the superiority of the SCA regarding the GCA. The same applies to the estimates of non-reciprocal hybrids based on $\mathrm{G} 7$ genotype, which is superior to $\mathrm{G} 7 \times \mathrm{G} 8$ and $\mathrm{G} 7 \times \mathrm{G} 5$ reciprocal, being lower when crossed with other genotypes. Estimates of GCA from non-reciprocal hybrids obtained based on the G8 genotype were in general, always higher than the reciprocal. Except when crossed with G2 genotype, although both had a similar GCA estimate values.

\section{Conclusions}

The characteristic of seed longevity was due to additive and non-additive gene effects, depending on the crossing evaluated;

The maternal effect was highly significant, it proved to be important for crosses between parents with low estimate of GCA;

The prediction of hybrid corn seed storage time must be made from seeds from the cross that originates the referred hybrids, with the female and male parents in their correct positions, and not considering only data from homozygous females or different hybrid compounds for the same female. 


\section{Acknowledgements}

To Syngenta Seeds, represented by Quality and PPT teams, to the Fundação de Amparo à Pesquisa do Estado de Minas Gerais (FAPEMIG), to the Conselho Nacional de Desenvolvimento Científico e Tecnológico (CNPq) and to the Coordenação de Aperfeiçoamento de Pessoal de Nível Superior (CAPES) for the financial and technical support for this project.

\section{References}

Andrade, T., Von Pinho, E. V. R., Von Pinho, R. G., Oliveira, G. E., Andrade, V., \& Fernandes, J. S. (2013). Physiological quality and gene expression related to heat-resistant proteins at different stages of development of maize seeds. Genetics and Molecular Research, 12(3), 3630-3642. https://doi.org/10.4238/ 2013.September.13.7

Barla-Szabo, G., Bocsi, J., Dolinka, B., \& Odiemah, M. (1989) Diallel analysis of seed vigor in maize. Seed Science and Technology, 18, 721-729.

Brasil, Ministério da Agricultura, Pecuária e Abastecimento. (2009). Regras Para Análise de Sementes. Secretaria de Defesa Agropecuária: Brasília.

Cabral, P. D. S., Amaral Jr., A. T., Vieira, H. D., Santos, J. S., Freitas, I. L. J., \& Pereira, M. G. (2013). Genetic effects on seed quality in diallel crosses of popcorn. Ciência e Agrotecnologia, 37(6), $502-511$. https://doi.org/10.1590/S1413-70542013000600003

Conrado, T. V., Scapim, C. A., Bignotto, L. S., Pinto, R. J. B., Freitas, I. L. J., Amaral Jr., A. T., ... Pinheiro, A. C. (2014). Diallel analysis of corn for special use as corn grits: Determining the main genetic effects for corn gritting ability. Genetics and Molecular Research, 13(3), 6548-6556. https://doi.org/10.4238/2014. august. 26.5

Cruz, C. D. (2013). GENES-A software package for analysis in experimental statistics and quantitative genetics. Acta Scientiarum, 35(3), 271-276. https://doi.org/10.4025/actasciagron.v35i3.21251

Cruz, C. D., Regazzi, A. J., \& Carneiro, P. C. S. (2012). Modelos Biométricos Aplicados ao Melhoramento Genético (Vol. 1, 4th ed.). Viçosa, MG: UFV.

Fan, X. M., Zhang, Y. D., Yao, W. H., Bi, Y. Q., Liu, L., Chen, H. M., ... Kang, M. S. (2013). Reciprocal diallel crosses impact combining ability, variance estimation, and heterotic group classification. Crop Science, 54(1), 89-97. https://doi.org/10.2135/cropsci2013.06.0393

Gomes, M. S., Von Pinho, E. V. R., Von Pinho, R. G., \& Vieira, M. G. G. C. (2000). Efeito da heterose na qualidade fisiológica de sementes de milho. Revista Brasileira de Sementes, 22(1), 7-17. https://doi.org/ 10.17801/0101-3122/rbs.v22n1p7-17

Griffing, B. (1956). Concept of general and specific combining ability in relation to diallel crossing systems. Australian Journal of Biological Sciences, 9, 463-493.

Laude, T. P., \& Carena, M. J. (2015). Genetic diversity and heterotic grouping of tropical and temperate maize populations adapted to the northern U.S. Corn Belt. Euphytica, 204(3), 661-677. https://doi.org/10.1007/ s10681-015-1365-8

Marcos-Filho, J. (1999). Teste de envelhecimento acelerado. In F. C. Krzyzanowski, R. D. Vieira, \& J. B. França Neto (Eds.), Vigor de sementes: Conceitos e testes. Londrina: ABRATES.

Moterle, L. M., Braccini, A. L., Scapim, C. A., Pinto, R. J. B., Gonçalves, L. S. A., Rodrigues, R., ... Amaral Jr., A. T. (2012). Combining ability of popcorn lines for seed quality and agronomic traits. Euphytica, 185(3), 337-347. https://doi.org/10.1007/s10681-011-0458-2

Moterle, L. M., Braccini, A. L., Scapim, C. A., Pinto, R. J. B., Gonçalves, L. S. A., Amaral Jr., A. T., ... Silva, T. R. C. (2011). Combining ability of tropical maize lines for seed quality and agronomic traits. Genetics and Molecular Research, 10(3), 2268-2278. https://doi.org/10.4238/vol10-3gmr1129

Nerling, D., Coelho, C. M. M., \& Brummer, A. (2018). Biochemical profiling and its role in physiological quality of maize seeds. Journal of Seed Science, 40(1), 007-015. https://doi.org/10.1590/2317-1545v40n 1172734

Nerling, D., Coelho, C. M. M., \& Nodari, R. O. (2013). Genetic diversity for physiological quality of seeds from corn (Zea mays L.) intervarietal crossbreeds. Journal of Seed Science, 35(4), 449-456. https://doi.org/ $10.1590 /$ S2317-15372013000400006 
Odiemah, M. (1989). Quantitative inheritance of seed quality characteristics in maize (Zea mays L.). Cereal Research Communications, 17(3), 245-251.

Oliveira, G. E., Von Pinho, E. V. R., Andrade, T., Souza, J. C., Caixeta, F., \& Ferreira, R. A. D. C. (2015). Relationship among physiological quality, heterosis, and amylase gene expression in maize seeds. Genetics and Molecular Research, 14(3), 8623-8633. https://doi.org/10.4238/2015.July.31.10

Oliveira, G. E., Von Pinho, R. G., Andrade, T., Von Pinho, E. V. R., Santos, C. D., \& Veiga, A. D. (2013). Physiological quality and amylase enzyme expression in maize seeds. Ciência e Agrotecnologia, 37(1), 40-48. https://doi.org/10.1590/S1413-70542013000100005

Pesev, N. V. (1970). Genetic factors affecting maize tolerance to low temperatures at emergence and germination. Theoretical and Applied Genetics, 40, 350-356. https://doi.org/10.1007/BF00285413

Prazeres, C. S., \& Coelho, C. M. M. (2016). Heterose para qualidade fisiológica de sementes na obtenção de híbridos de milho. Revista Brasileira de Milho e Sorgo, 15(1) 124-133. https://doi.org/10.18512/1980-6477/ rbms.v15n1p124-133

Ramalho, M. A. P., Abreu, A. F. B., Santos, J. B., \& Nunes, J. A. R. (2012). Aplicações da Genética Quantitativa no Melhoramento de Plantas Autógamas. Lavras: UFLA.

Reis, L. S., Pereira, M. G., Silva, R. F., \& Meireles, R. C. (2011). Efeito da heterose na qualidade de sementes de milho doce. Revista Brasileira de Sementes, 33(2), 10-315. https://doi.org/10.1590/S0101-31222011000 200013

Santos, H. O., Von Pinho, I. V., Von Pinho, E. V. R., Pires, R. M. O., Silva, V. F., Carvalho, M. L. M., ... Oliveira, R. M. E. (2016). Physiological quality of hybrid maize seeds through respiratory and enzymatic activities. African Journal of Agricultural Research, 11(20), 1879-1886. https://doi.org/10.5897/AJAR2015.10457

SAS Institute Inc. (2012). JMP®, Version 10. SAS Institute Inc., Cary, NC.

\section{Copyrights}

Copyright for this article is retained by the author(s), with first publication rights granted to the journal.

This is an open-access article distributed under the terms and conditions of the Creative Commons Attribution license (http://creativecommons.org/licenses/by/4.0/). 